\title{
DEVELOPEMENT OF A VEGETABLE DRYER
}

\author{
Iyidiobu Blessing Ngozi, Awulu John Okanagba \\ Department of Agricultural and Environmental Engineering \\ Federal University of Agriculture Makurdi, Benue Nigeria
}

\begin{abstract}
A Vegetable dryer of dimension $1.50 \mathrm{~m}$ (high) $\mathrm{x}$ $0.72 \mathrm{~m}$ (wide) x $0.59 \mathrm{~m}$ (breadth) was developed using mild steel iron and its performance evaluated. The device consists of a drying chamber with three drying trays; fans incorporated for heat circulation, a heating element of $2000 \mathrm{~W}$, four swivel caster rollers for ease of mobility, a thermostat to regulate the heat generated in the drying chamber and a thermo-gauge inserted to monitor the temperature in the drying chamber. The vegetable dryer has a drying capacity of $34 \mathrm{~kg}$ and three compartments of $0.25 \mathrm{~m}$ equal spacing. The dryer is partitioned at $0.75 \mathrm{~m}$, $0.1 \mathrm{~m}$ and $1.25 \mathrm{~m}$ from the heating element, with the first (bottom) tray, the second tray (middle) and the third (upper) respectively. The device performance was evaluated under no-load and load conditions at $50{ }^{\circ} \mathrm{C}, 60$ ${ }^{\circ} \mathrm{C}$, and $80{ }^{\circ} \mathrm{C}$ temperatures with three replications. Results obtained under no-load indicated that temperatures very close to the preset values (by the thermostat) were attained within 5 mins. Under load condition, the dryer was evaluated by drying $16.74 \mathrm{~kg}$ of tomatoe slices at $50{ }^{\circ} \mathrm{C}, 60^{\circ} \mathrm{C}$, and $80{ }^{\circ} \mathrm{C}$. Weight reduction (degree of moisture loss) from the slices was recorded at intervals of 1hour until a nearly constant weight was obtained. The result revealed that the dryer has a mean drying efficiency of $80.6 \%$ and drying rate of $0.02 \mathrm{~kg} / \mathrm{hr}$. At a drying time of 10 hours and temperatures of $50{ }^{\circ} \mathrm{C}$ and $60{ }^{\circ} \mathrm{C}, 16.74 \mathrm{~kg}$ of tomatoes were reduced to $1.23 \mathrm{~kg}$ and $1.13 \mathrm{~kg}$ representing $93 \%$ (wb) of removed moisture, while a final weight of $1.08 \mathrm{~kg}$ dry matter was obtained from the same starting weight of wet tomatoes at $80{ }^{\circ} \mathrm{C}$ representing $94 \%$ (wb) of moisture loss for the same drying time. ANOVA studies indicated that the effect of temperature and tray level on drying of vegetable (tomatoes) were highly significance at $(P<5 \%)$. The dried vegetable (tomatoes) is free from dust and any form of contamination making it healthy for consumption.
\end{abstract}

Keywords-Vegetable-dryer, Drying-efficiency, dryingrate, tomatoes, airflow-rate.

\section{INTRODUCTION}

Vegetables form an essential part of balanced diet. Thus they represent an important part of world agricultural food production. This explains the popularity of tomatoes, even among other vegetables. It is second in world vegetable acreage and first in terms of industrialised volume [1]. The production rate of tomatoes in Nigeria is also very high.
Nigeria is the second largest producer of tomatoes in Africa [1]. However, 65,809 metric tons of tomatoes are imported annually. This results from high production losses incurred by its high moisture content which makes it highly perishable, and other varied post-harvest problems. Attempts to solve these problems by moisture reduction have had their flaws: On the one hand, the traditional method of sun drying is a manual labour intensive process that causes poor food quality. On the other, various sophisticated drying methods and machines that efficiently reduce the moisture content of tomatoes without compromising its quality can only be afforded by large multinational firms because of their high cost.

Sun-drying of tomatoes takes long drying time, contaminates tomatoe fruits through dusts, soil and insects and leaves the fruits at a high moisture content well above $10 \%$ at the end of drying. This makes them unfit for storage [2-4]. Solar drying by natural convection is an improvement on sun drying that only slightly increases drying rate and product quality but fails on temperature control $[5,6,7,8,9,10]$. A forced convection dryer developed by [9] achieved a drying efficiency of $31 \%$ without compromising the original quality of the tomato slices after drying. Its performance even so, was weather dependent. Thin-layer drying models have been used to evaluate the drying kinetics of a model cabinet solar dryer and a vacuum assisted dryer designed by [11]. They showed that tomato slices of $8 \mathrm{~mm}$ thickness and $100 \mathrm{~g}$ mass experienced an 82.5 $\%$ moisture loss, 135 minutes faster than in sun drying method without appreciable damage to their natural quality. Liberty [12] incorporated a heat storage system in a passive solar dryer to reduce dependence on weather conditions. This resulted in a sustained drying process hours after sunset. A drying temperature of $68.2{ }^{\circ} \mathrm{C}$ at an ambient temperature of $32.8{ }^{\circ} \mathrm{C}$ caused an $87 \%$ moisture loss within a drying time of 5 days as opposed to the 3 weeks of open sun-drying for the same mass of tomatoes. A low cost convective dryer developed by [13] achieved efficient drying but incurred high drying costs per hour.

There is thus a need to develop a vegetable drying machine that neither compromises energy conservation and food quality nor incurs great costs in construction, operation and maintenance. This work developed an energy efficient dryer that has low initial costs, ease of construction, operation and maintenance. This machine would allow farmers to harvest their vegetables with some flexibility and more independently of prevailing season-dictated prices in the market since 


\section{International Journal of Engineering Applied Sciences and Technology, 2021 \\ Vol. 5, Issue 11, ISSN No. 2455-2143, Pages 77-82 \\ Published Online March 2021 in IJEAST (http://www.ijeast.com)}

harvested crops can be stored for longer. This advantage may also apply if the machine is used for other vegetables.

\section{MATERIALS AND METHOD}

\section{A. Materials for Construction}

I The component parts of the dryer include a chamber which consists of drying trays, a heating element to generate the heat required to dry the vegetable and a thermostat probe, thermo-gauge for reading the drying chamber temperature. Fans were incorporated to circulate the heat generated by the heating element and create a mixed convectional heating of the vegetable slices. The thermostat was used for regulating the heat generated by the heating element. Galvanized mild steel formed the main body of dryer with four rollers at the base for easy of mobility as show in Figure 1 a.

The fan is a ducted mechanical type (centrifugal) that produces more pressure for a given air volume. The heating element used is a $2000 \mathrm{~W}$ Nichrome wire (ribbon). The lagging material was prepared from fiberglass. Fibreglass is a material made from extremely fine fibers of glass. It is useful because of is high ratio of surface area to weight. It has a Thermal conductivity of $0.032 \mathrm{~W} / \mathrm{mK}$, Embodied carbon of $1.35 \mathrm{CO}_{2} / \mathrm{kg}$ and Embodied energy $=28 \mathrm{MJ} / \mathrm{kg}$ [14]. The galvanized mild steel applied has an internal layer constituting the interior of the drying chamber and external layer which forms the visible exterior covering of the dryer. The thermal conductivity of the galvanized sheet metal is $0.36 \mathrm{~W} / \mathrm{mK}$. [15]. Part drawings of the completed vegetable dryer are depicted in Figure $1 \mathrm{~b}$.

Design values for various drying parameters have been presented along with appropriate reference equations in Table 1.

The following terms have been defined for Table 1.: $\mathbf{D}_{\mathbf{m}}=$ dry matter weight $(\mathrm{kg}) ; \boldsymbol{W}_{m}=$ Weight of fresh tomatoes $(\mathrm{kg})$; $\boldsymbol{M}_{\text {ciw }}=$ initial moisture content of product (before drying) wet basis (\%); $\mathbf{d}=$ diameter of the fan blade (m); $\mathbf{N}=$ the fan revolution (rpm); $\Delta \boldsymbol{w}=$ change in weight of product at time $\mathrm{t}$ $(\mathrm{kg}) ; \mathbf{A}=$ area of the dryer $\left(\mathrm{m}^{2}\right) ; \Delta \mathrm{T}=$ change in temperature $\left({ }^{\circ} \mathrm{C}\right) ; \boldsymbol{w}_{i}=$ weight before drying $(\mathrm{kg})$;

$w_{f}=$ weight after drying $(\mathrm{kg})$;

$\boldsymbol{t}_{i}=$ time before drying $_{(\mathrm{h}) ;} \boldsymbol{t}_{f}=$ time after drying $(\mathrm{h})$;

Other terms defined for Table 1 are: $\boldsymbol{C}_{\boldsymbol{c}}=$ Specific heat capacity of tomato $\left(3.98 \mathrm{~kJ} / \mathrm{kg}{ }^{\circ} \mathrm{C}\right) ; \boldsymbol{M}_{\alpha=}$ mass of product

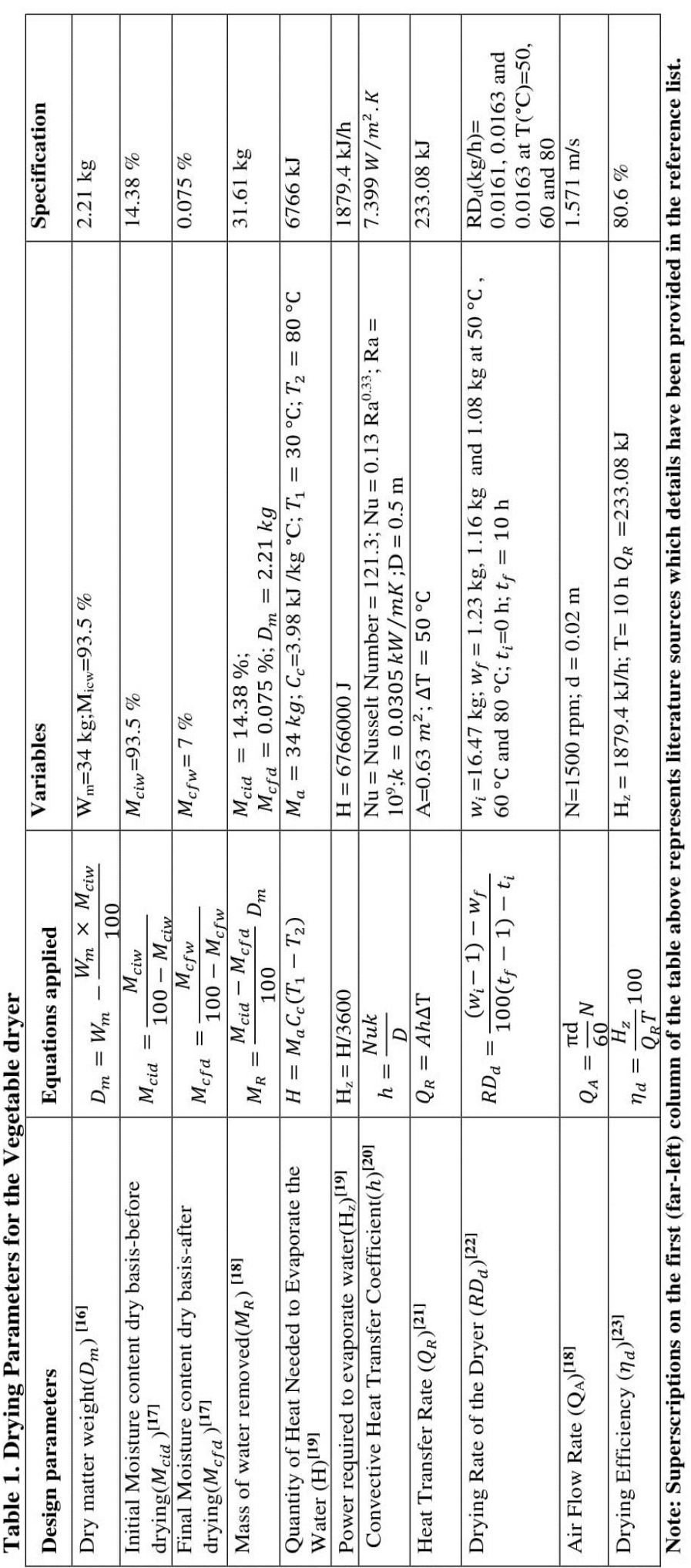

$(\mathrm{kg}) ;\left(T_{1}-T_{2}\right)=$ Temperature difference in the cabinet $\left({ }^{\circ} \mathrm{C}\right)$; $\mathbf{M}=$ mass of the heating element $(\mathrm{kg}) ; \mathbf{C}=$ heat capacity of 
heating element $\left(\mathrm{J} / \mathrm{kg}{ }^{\circ} \mathrm{C}\right) ; \boldsymbol{T}_{f}-\boldsymbol{T}_{\tilde{i}}=$ change in temperature $\left({ }^{\circ} \mathrm{C}\right) ; \mathbf{R a}=$ Rayleigh Number $; \boldsymbol{\eta}_{d=}$ drying efficiency $(\%)$; $\boldsymbol{H}_{\boldsymbol{z}}=$ heat required to remove moisture $(\mathrm{kJ} / \mathrm{h}) ; \boldsymbol{Q}_{\boldsymbol{R}}=$ heat transfer rate $(\mathrm{kJ} / \mathrm{h}) ; \mathbf{t}=$ drying time $(\mathrm{h}) ; \mathrm{k}=$ Thermal Conductivity(w/m.k); $\mathrm{D}=$ Hydraulic diameter (m).

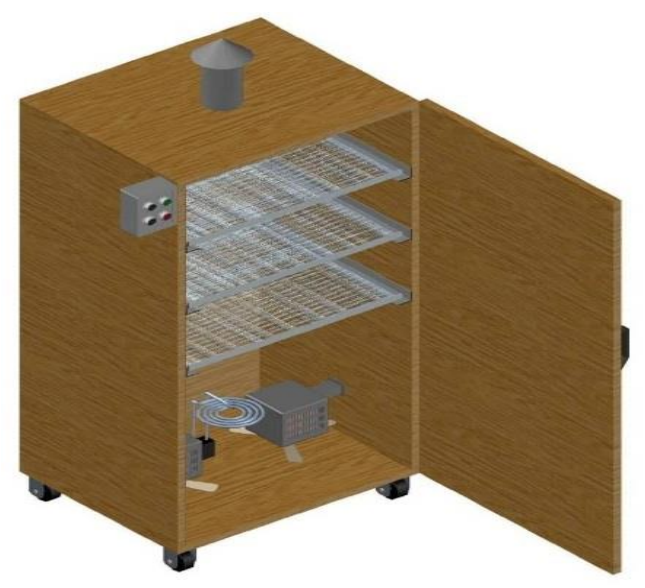

Figure 1 a. Assembled drawing of the vegetable dryer

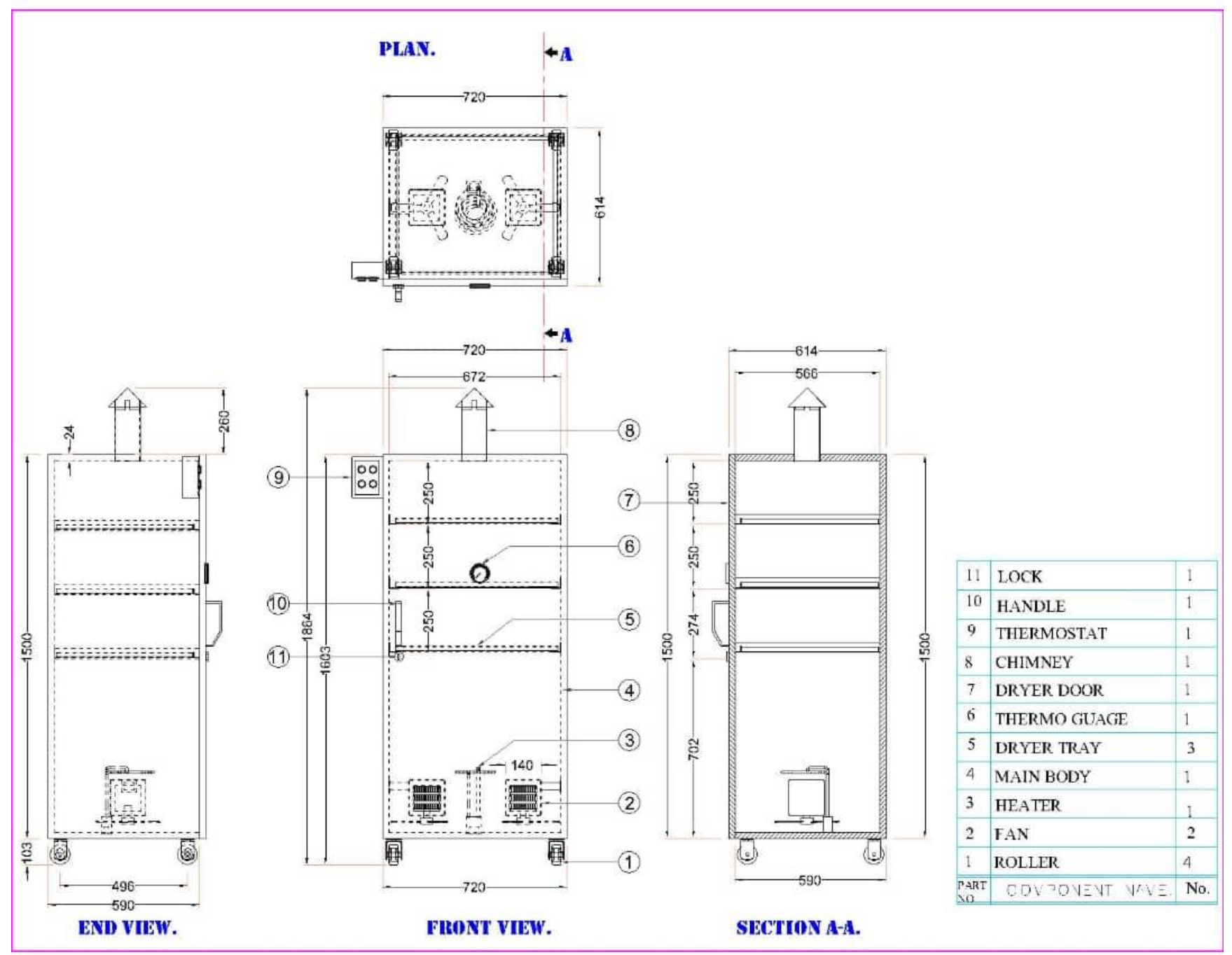

Figure 1 b. Part drawings of the vegetable dryer 


\section{International Journal of Engineering Applied Sciences and Technology, 2021 \\ Vol. 5, Issue 11, ISSN No. 2455-2143, Pages 77-82 \\ Published Online March 2021 in IJEAST (http://www.ijeast.com)}

\section{$B$ Method of Evaluation}

The dryer was evaluated at both no-load and load conditions. The no-load test was first performed during which the thermostat of the dryer was set at temperatures of $50{ }^{\circ} \mathrm{C}, 60{ }^{\circ} \mathrm{C}$ and $80{ }^{\circ} \mathrm{C}$ and the temperature monitored over time at three tray levels (upper, middle and bottom) in the dryer. Temperature readings obtained on the trays were compared with the actual setting. This test was replicated three times for each the temperatures examined above. Testing at load condition was also performed and evaluated by using a split plot in Randomized Complete Block Design (RCBD) with temperatures $\left(50{ }^{\circ} \mathrm{C}, 60{ }^{\circ} \mathrm{C}\right.$ and $\left.80{ }^{\circ} \mathrm{C}\right)$ and tray levels (bottom, middle and upper) as factors.

$16.74 \mathrm{~kg}$ of UC-82B tomato variety, procured from a local market (Wadata) in Makurdi town of Benue state was used for each test at load condition. The samples were washed with portable water and sliced into four equal sizes of $8 \mathrm{~mm}$ to 15 $\mathrm{mm}$ thickness each, along the minor axis using a stainless steel knife. These were dried at the three tray levels, each tray containing $5.58 \mathrm{~kg}$ of sliced tomatoes evenly spread. The temperatures and the moisture losses were monitored over time until a nearly constant weight of the material was obtained. The effect of temperature and tray level were then observed, recorded and analysed.

\section{RESULTS AND DISCUSSION}

\section{A Results}

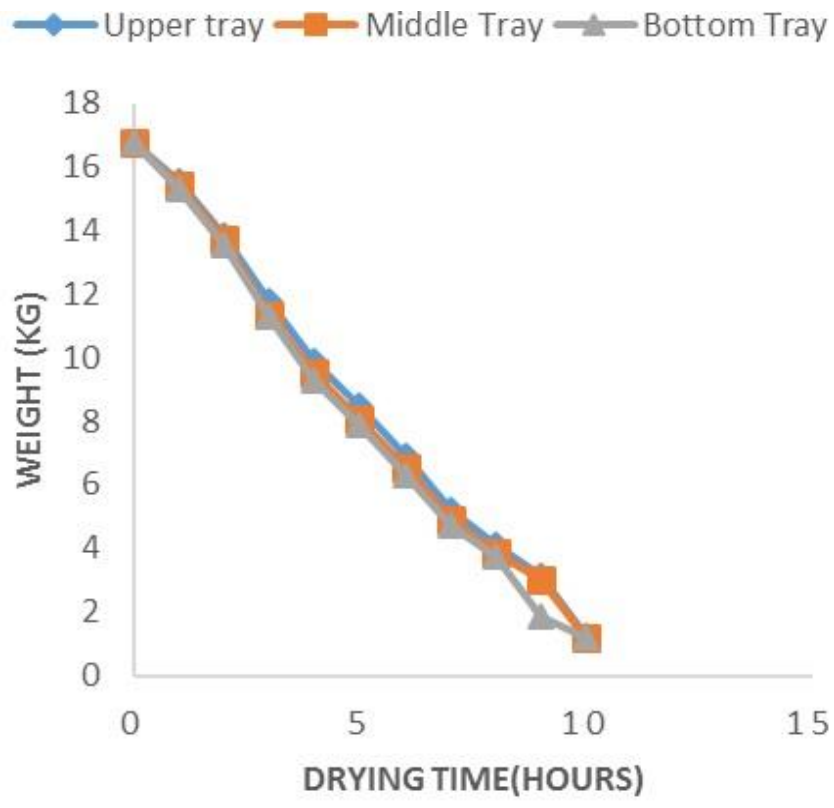

Figure 2a. Mean weight reduction at $50{ }^{\circ} \mathrm{C}$

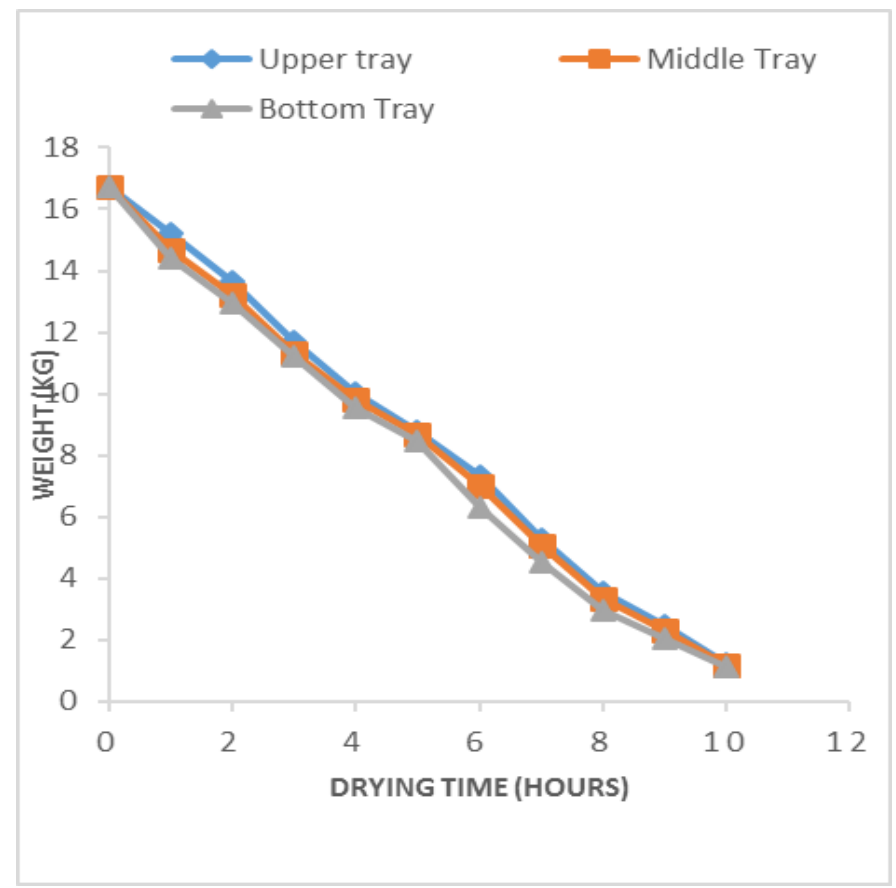

Figure 2b. Mean weight reduction at $60{ }^{\circ} \mathrm{C}$

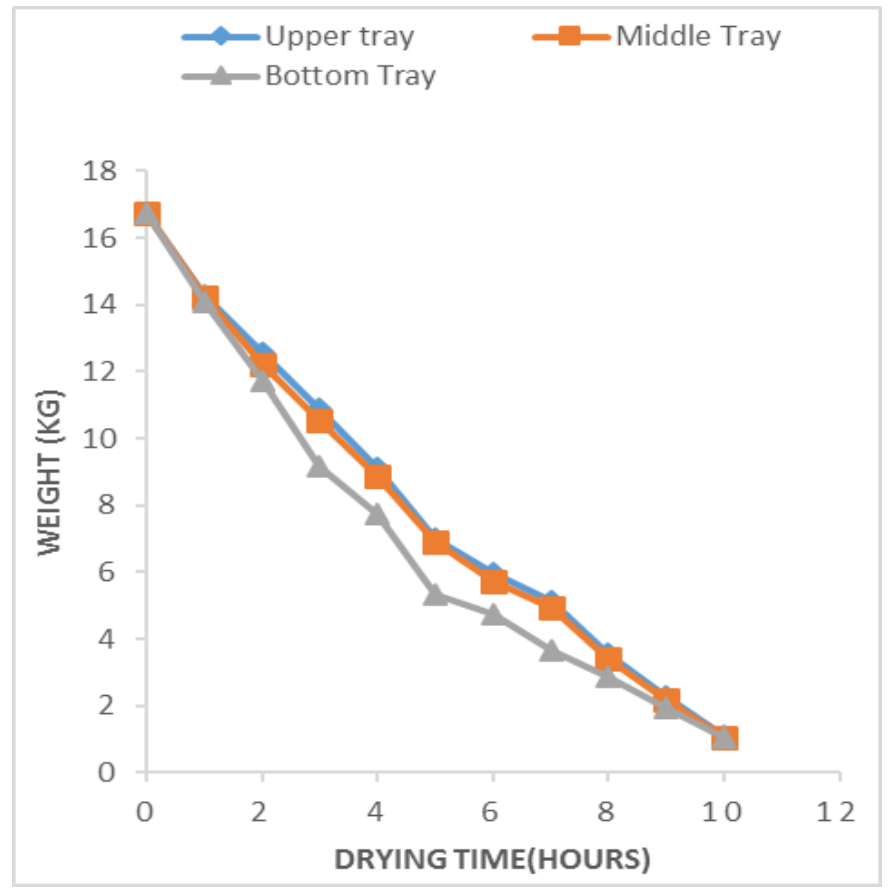

Figure 2c. Mean weight reduction at $80^{\circ} \mathrm{C}$ 
Table 2. Mean Tray Temperatures at No-load Condition

\begin{tabular}{ccccc}
\hline $\begin{array}{c}\text { Thermosta } \\
\mathbf{t}\end{array}$ & Tray level & \multicolumn{3}{c}{ Temperature $\left({ }^{\circ} \mathbf{C}\right)$} \\
$\begin{array}{c}\text { Setting } \\
\left({ }^{\circ} \mathbf{C}\right)\end{array}$ & & $\begin{array}{c}\text { at 5 } \\
\text { min }\end{array}$ & $\begin{array}{c}\text { at } \mathbf{~} \text { min } \\
\text { at 15 min }\end{array}$ \\
\hline 50 & Upper tray & 48 & 50 & \\
50 & Middle tray & 49 & 50 & 50 \\
50 & Bottom tray & 50 & 50 & 50 \\
60 & Upper tray & 58 & 60 & 60 \\
60 & Middle tray & 59 & 60 & 60 \\
60 & Bottom tray & 60 & 60 & 60 \\
80 & Upper tray & 79 & 80 & 81 \\
80 & Middle tray & 80 & 80 & 80 \\
80 & Bottom tray & 80 & 80 & 80 \\
\hline
\end{tabular}

Table 3. Mean Weight/Moisture Loss $(\%)$ Wb per Test

\begin{tabular}{|c|c|c|c|c|}
\hline $\begin{array}{l}\text { Temperature } \\
\left({ }^{\circ} \mathbf{C}\right)\end{array}$ & Replication & $\begin{array}{r}W_{1} \\
(k g)\end{array}$ & $\begin{array}{l}W_{2} \\
(\mathbf{k g})\end{array}$ & $\begin{array}{c}\text { Moisture } \\
\text { Removed } \\
(\%) \text { Wb }\end{array}$ \\
\hline 50 & 1 & 16.74 & 1.23 & 92.7 \\
\hline 50 & 2 & 16.74 & 1.24 & 92.6 \\
\hline 50 & 3 & 16.74 & 1.21 & 92.8 \\
\hline Average & & 16.74 & 1.23 & 93 \\
\hline 60 & 1 & 16.74 & 1.15 & 93.1 \\
\hline 60 & 2 & 16.74 & 1.19 & 93.0 \\
\hline 60 & 3 & 16.74 & 1.13 & 93.2 \\
\hline Average & & 16.74 & 1.16 & 93 \\
\hline 80 & 1 & 16.74 & 1.08 & 93.5 \\
\hline 80 & 2 & 16.74 & 1.09 & 95.5 \\
\hline 80 & 3 & 16.74 & 1.07 & 93.6 \\
\hline Average & & 16.74 & 1.08 & 94 \\
\hline
\end{tabular}

Table 4: Effect of Temperature Variation on Tomato Drying

\begin{tabular}{|c|c|c|c|c|c|}
\hline $\begin{array}{l}\text { Source of } \\
\text { Variance }\end{array}$ & $\begin{array}{l}\begin{array}{l}\text { Degree } \\
\text { of }\end{array} \\
\text { freedom } \\
\text { (DF) }\end{array}$ & $\begin{array}{l}\text { Sum of } \\
\text { Squares } \\
\text { (SS) }\end{array}$ & $\begin{array}{l}\text { Mean } \\
\text { Square } \\
\text { (MS) }\end{array}$ & $\begin{array}{c}\mathbf{F} \\
\text { Calc }\end{array}$ & $\begin{array}{c}F \\
(0.05)\end{array}$ \\
\hline
\end{tabular}

\begin{tabular}{llllll}
\hline Treatment & 2 & 0.0017 & 0.000567 & $18.00^{*}$ & 1.73 \\
Error & 18 & 0.0328 & 0.0000315 & & \\
Total & 20 & 0.0345 & & & \\
& & & & & \\
\hline
\end{tabular}

$*=$ significant difference at $\mathrm{p}=0.05$

Table 5: Effect of Drying Tray-Heater Proximity on Tomato Drying

\begin{tabular}{llllcc}
\hline $\begin{array}{l}\text { Source of } \\
\text { Variance }\end{array}$ & $\begin{array}{l}\text { Degree } \\
\text { of } \\
\text { freedom } \\
\text { (DF) }\end{array}$ & $\begin{array}{l}\text { Sum of } \\
\text { Squares } \\
\text { (SS) }\end{array}$ & $\begin{array}{l}\text { Mean } \\
\text { Square } \\
\text { (MS) }\end{array}$ & $\begin{array}{c}\text { F } \\
\text { Calc }\end{array}$ & $\begin{array}{c}\text { F } \\
(\mathbf{0 . 0 5})\end{array}$ \\
\hline Treatment & 2 & 0.0403 & 0.0134 & $15.9^{*}$ & 1.73 \\
Error & 18 & 0.0152 & 0.0000844 & & \\
Total & 20 & 0.0555 & & & \\
\hline
\end{tabular}

$*=$ significant difference at $\mathrm{p}=0.05$

\section{$B$ Discussion}

Table 2 presents means of no-load evaluation of the vegetable dryer under thermostat settings of $50{ }^{\circ} \mathrm{C}, 60{ }^{\circ} \mathrm{C}$ and $80^{\circ} \mathrm{C}$ with three replications respectively. The mean time taken for the drying system to reach the set temperature of $50{ }^{\circ} \mathrm{C}$ and 60 " $\mathrm{C}$ was 5 minutes while it took the drying system less than 5 minutes to reach set temperature of $80{ }^{\circ} \mathrm{C}$. However, it was observed that the temperatures in the bottom tray closer to the heating element assumed equal temperature with the thermostat setting almost immediately. The uniformity of temperature after 5 minutes at $50{ }^{\circ} \mathrm{C}, 60{ }^{\circ} \mathrm{C}$ and $80{ }^{\circ} \mathrm{C}$ in the drying system agreed with [24] which stated that the uniform temperature in the dryer chamber was achieved after some time due to the convection current created in the drying system chamber by the fans.

Figures $2 \mathrm{a}, 2 \mathrm{~b}$ and $2 \mathrm{c}$ are drying curves of mean weight reduction at various tray levels under thermostat settings of 50 ${ }^{\circ} \mathrm{C}, 60{ }^{\circ} \mathrm{C}$ and $80{ }^{\circ} \mathrm{C}$. The result obtained indicated that there was a gradual reduction of tomatoe weight from $16.74 \mathrm{~kg}$ until a nearly constant weight or appreciable weight reduction was achieved. A summary of replications of events in drying curve are presented in Table 3. The table for instance shows mean weight reduction at $50{ }^{\circ} \mathrm{C}$ and $60{ }^{\circ} \mathrm{C}$ from $16.74 \mathrm{~kg}$ to $1.2 \mathrm{~kg}$ after ten (10) hours representing $93 \%$ (wb) of mean moisture removed. However, a mean weight reduction of $94 \%$ from $16.74 \mathrm{~kg}$ to $1.1 \mathrm{~kg}$ was recorded at $80{ }^{\circ} \mathrm{C}$ for the same drying time. This result agreed with the research findings of $[13,25]$ that moisture loss in a wet sample of vegetable is directly proportional to temperature with time. Analysis of variance for the effect of temperature on mean weight reduction (moisture removed) in Table 4 confirms this relationship. It shows that the effect of temperature on moisture removal with time is significant.

The drying curves in Figures $2 \mathrm{a}, 2 \mathrm{~b}$ and $2 \mathrm{c}$ show higher weight reductions at the bottom tray closer to the heating element at all set temperatures. Wet fresh cut tomatoes dried at $50{ }^{\circ} \mathrm{C}$ for 10 hours for instance, shrank from $16.74 \mathrm{~kg}$ to 1.18 $\mathrm{kg}, 1.22 \mathrm{~kg}$ and $1.28 \mathrm{~kg}$ on the bottom, middle and upper trays 


\section{International Journal of Engineering Applied Sciences and Technology, 2021 \\ Vol. 5, Issue 11, ISSN No. 2455-2143, Pages 77-82 \\ Published Online March 2021 in IJEAST (http://www.ijeast.com)}

respectively. Moreso, these tomatoes when dried at $80{ }^{\circ} \mathrm{C}$ for 10 hours, shrank from $16.74 \mathrm{~kg}$ to $1.06 \mathrm{~kg}, 1.07 \mathrm{~kg}$ and $1.11 \mathrm{~kg}$ on the bottom, middle and upper trays respectively. These results indicated that weight loss at the bottom trays equaled those on other trays in shorter time. The variation in the weight reduction at each tray level was assumed to be primarily due to the proximity of the bottom tray to the heating element of the system. This view also agrees with the findings of $[9,24,25]$ that increase in the distance between a product and the heating element, increases the drying time because of a reduction of heat transfer to the product thus resulting in slow rate of moisture removal. Analysis of variance for the effect of tray on mean weight reduction (moisture removed) in Table 5 confirms this relationship. It shows the effect of tray proximity to heating element on moisture removal with time as significant.

All three drying curves in Figure 2 were obtained at a constant fan speed of and airflow rate of $1500 \mathrm{rpm}$ and $1.571 \mathrm{~m} / \mathrm{s}$ respectively. The decrease in weight with time as shown in these figures indicated that drying time depended only on weight (water content) of the product to be dried. A comparison of the time and weight axes reveals that time required to reach dryness (constant weight) is less if the initial weight is decreased. This view is also in line with the report of [26] that drying rate of various agricultural products is independent of air flow rate, not product mass. Therefore, the more weight there is, the longer the time required to remove its moisture at constant temperature.

Furthermore, Figures $2 \mathrm{a}, 2 \mathrm{~b}$ and $2 \mathrm{c}$ when enlarged, indicate that the gradient of each curve at all tray levels and temperatures examined was steeper at the start of drying than at end of drying. This is because tomatoe pore spaces are initially large at the start of the drying, when the initial moisture content of tomatoe samples is high. These pore spaces contract as the drying proceeds, concentrating the dry matter and slowing down evaporation of moisture with time. This agrees with the drying time equation developed by [27].

\section{CONCLUSION}

An electrically powered vegetable dryer was successfully developed and its performance evaluated. The dryer achieved a drying efficiency of $80.6 \%$ with drying capacity of $24 \mathrm{~kg}$ of vegetable (tomatoes) per batch. The average drying rate of the device was $0.02 \mathrm{~kg} / \mathrm{hr}$ at drying time of 10 hours. The weight (moisture) loss of vegetable increased with increase in temperature and its proximity to source of heat. ANOVA result proved that there was significant difference on drying rate as temperature and dryer tray level was varied.

Further research work should be carried out with the drying system trays intermittently swapped for uniformity of drying. Products should also be investigated at varying air flow rate. The drier constructed should be tested with different vegetables to ascertain the possibility of improved performance. The inclusion of an alternative energy source in the drying system should also be explored.

\section{REFERENCES}

[1] FAO (2021). Food and Agricultural Organisation. Cropsdata in Faostat. http://www.fao.org/faostat/en/\#data/QC

[2] Hussein, J. B., Sanusi, M. S., and Filli, K. B. (2016). Evaluation of Drying Methods on the Content of Some Bio-Actives (lycopene,-carotene and ascorbic acid) of Tomato Slices. African Journal of Food Science, 10(12), 359-367.

[3] Sahdev, R. K. (2014). Open Sun and Greenhouse Drying of Agricultural and Food Products. A Review. International Journal of Engineering,3(3), 1053-1066.

[4] Ramaswamy, H. S., and Marcotte, M. (2006). Food Processing: Principles and Applications. CRC Press.

[5] Forson, F. K., Nazha, M. A. A., Akuffo, F. O., and Rajakaruna, H. (2007). Design of Mixed-Mode Natural Convection Solar Crop Dryers: Application of Principles and Rules of Thumb. Renewable Energy, 32(14), 23062319.

[6] Belessiotis, V., and Delyannis, E. (2011). Solar Drying. Solar Energy, 85(8), 1665-1691.

[7] Sontakke, M. S., and Salve, S. P. (2015). Solar Drying Technologies: A Review. International Journal of Engineering Science, 4, 29-35.

[8] Bena, B., and Fuller, R. J. (2002). Natural Convection Solar Dryer with Biomass Back-Up Heater. Solar energy, 72(1), 75-83.

[9] Abdullahi, AF (2007). Development and Performance Evaluation of an on-Farm Forced Convection Solar Dryer for Tomato. Master of Science Thesis, Amadu Bello University, Zaria, Nigeria.

[10] Bala, B. K., and Janjai, S. (2009, January). Solar Drying of Fruits, Vegetables, Spices, Medicinal Plants and Fish: Developments and Potentials. In International Solar Food Processing Conference (pp. 14-16).

[11] Rajkumar, P. (2007). Comparative Performance of Solar Cabinet, Vacuum Assisted Solar and Open Sun Drying Methods. Master of Science Thesis, McGill University, Canada.

[12] Liberty, J.T. (2014) Design, Construction and Performance Evaluation of a Postharvest Heat Storage Solar Energy Crop Dryer. Master of Science Thesis, University of Nigeria, Nsukka, Virtual Library.

[13] De-Carvalho, R. O., Machado, M. B., Scherer, V. S., Fuentes, G. C., Da-Luz, C. A. S., and Da-Luz, M. L. G. S. 


\section{International Journal of Engineering Applied Sciences and Technology, 2021 \\ Vol. 5, Issue 11, ISSN No. 2455-2143, Pages 77-82 \\ Published Online March 2021 in IJEAST (http://www.ijeast.com)}

(2015). Drying Tomatoes in a Small Tray Dryer. Agricultural Engineering International: CIGR Journal.

[14] ITDG (2006).Tomato Processing. Intermediate Technology Development Group. Warwickshire, London.

[15] A. S. H. R. A. E. (1977). American Society of Heating Refrigerating and Air-Conditioning Engineers. Fundamentals Handbook, Inc, Atlanta.

[16] Williams, S. (1984). Official Methods of Analysis (No. 630.24 A8 1984). Association of Official Analytical Chemists.

[17] Keey, R. B. (1991). Drying of Loose and Particulate Materials. CRC Press, Taylor and Francis Group, United Kingdom. 514pp.

[18] Ajisegiri, E. S. A., Alabadan, B. A., and Uche, I. K. (2006). Development of artificial dryer for yam chips. In Proceedings of the 7th International Conference and 28th Annual General Meeting of the Nigerian Institution of Agricultural Engineers. ABU, Zaria , 28, 348.

[19] Khan, M. Z. H., Al-Mamun, M. R., Sikdar, S., Halder, P. K., and Hasan, M. R. (2016). Design, Fabrication, and Efficiency Study of a Novel Solar Thermal Water Heating System: Towards Sustainable Development. International Journal of Photoenergy.

[20] Cengel, Y. A., and Boles, M. A. (2002).Thermodynamics: An Engineering Approach. (5 th ed.) Sea, 1000, 8862.

[21] Duffie, J.A., Beckman, W.A. and Blair, N.(2020) Solar Engineering of Thermal Processes (5th ed.) Canada, John Wiley and Sons. 928pp.

[22] Amer, B. M. A. (1999). Determination of Drying Rate of Fruits as a Function of the Affecting Factors under Conditions Suiting Solar Drying (Doctoral dissertation, M. Sc. Thesis, Ag. Eng. Dept., Fac. of Agic., Cairo Univ., Egypt).

[23] Brenndorfer, B., Kennedy, L., Bateman, C. O., Trim, D. S., Mrema, G. C., and Wereko-Brobby, C. (1987). Solar Dryers-Their Role in Post-harvesting Processing. Commonwealth Science Council, Commonwealth Secretariat, London, 4-7.

[24] Owolarafe, O. K., Obayopo, S. O., Amarachi, O. A., Babatunde, O., and Ologunro, O. A. (2011). Development and Performance Evaluation of an Okra Drying Machine. Research Journal of Applied Sciences, Engineering and Technology, 3(9), 914-922.

[25] Sadin, R., Chegini, G. R., and Khodadadi, M. (2014). Development and Performance Evaluation of a Combined Infrared and Hot air Dryer. Journal of Biological and Environmental Sciences, 8(22), 11-18.

[26] Hutchinson, D., and Otten, L. (1983). Thin-layer Air Drying of Soybeans and White beans. International Journal of Food Science and Technology, 18(4), 507-522.

[27] Geankoplis, C. J. (1993). Drying of Process Materials. Transport Processes and Unit Operations, 520-583. 